\title{
Olive Fruit and Leaf Wastes as Bioactive Ingredients for Cosmetics-A Preliminary Study
}

\author{
María de la Luz Cádiz-Gurrea *(D), Diana Pinto (D), Cristina Delerue-Matos (D) and Francisca Rodrigues *(D) \\ REQUIMTE/LAQV, Instituto Superior de Engenharia do Porto, Rua António Bernardino de Almeida, \\ 4249-015 Porto, Portugal; diana.pinto@graq.isep.ipp.pt (D.P.); cmm@isep.ipp.pt (C.D.-M.) \\ * Correspondence: maria.gurrea@graq.isep.ipp.pt (M.d.1.L.C.-G.); francisca.rodrigues@graq.isep.ipp.pt (F.R.)
}

Citation: Cádiz-Gurrea, M.d.l.L.;

Pinto, D.; Delerue-Matos, C.; Rodrigues, F. Olive Fruit and Leaf Wastes as Bioactive Ingredients for Cosmetics-A Preliminary Study. Antioxidants 2021, 10, 245. https:// doi.org/10.3390/antiox10020245

Academic Editor: Martina Meinke Received: 29 December 2020

Accepted: 2 February 2021

Published: 5 February 2021

Publisher's Note: MDPI stays neutral with regard to jurisdictional claims in published maps and institutional affiliations.

\begin{abstract}
Olea europaea cultivar, native in the Mediterranean basin, has expanded worldwide, mainly due to the olive oil industry. This expansion is attributed to the benefits of olive oil consumption, since this product is rich in nutritional and bioactive compounds. However, the olive industry generates high amounts of wastes, which could be related to polluting effects on soil and water. To minimize the environmental impact, different strategies of revalorization have been proposed. In this sense, the aim of this work was to develop high cosmetic value added oleuropein-enriched extracts (O20 and $\mathrm{O} 30$ ), a bioactive compound from olive byproducts, performing a comprehensive characterization using high performance liquid chromatography coupled to mass spectrometry and evaluate their bioactivity by in vitro assays. A total of 49 compounds were detected, with oleuropein and its derivatives widely found in $\mathrm{O} 30$ extract, whereas iridoids were mainly detected in O20 extract. Moreover, 10 compounds were detected for the first time in olive leaves. Both extracts demonstrated strong antioxidant and antiradical activities, although $\mathrm{O} 30$ showed higher values. In addition, radical oxygen and nitrogen species scavenging and enzyme inhibition values were higher in $\mathrm{O} 30$, with the exception of $\mathrm{HOCl}$ and hyaluronidase inhibition assays. Regarding cell viability, olive byproduct extracts did not lead to a decrease in keratinocytes viability until $100 \mu \mathrm{g} / \mathrm{mL}$. All data reported by the present study reflect the potential of industrial byproducts as cosmetic ingredients.
\end{abstract}

Keywords: byproducts; olive leaves; olive fruits; revalorization; cosmetics; bioactive compounds; antioxidants

\section{Introduction}

Nowadays, olive trees (Olea europaea L.), native in the Mediterranean basin, have spread to many countries and adapted to different pedoclimatic conditions. This cultivar has expanded in Asia, America and Oceania mainly due to the olive oil industry, although the Mediterranean area is the most important region in terms of olives with almost $20 \mathrm{M}$ tons of olive production in 2018 [1].

This globally expansion during the past two decades is mainly related to the health promoting properties attributed to olive oil consumption since this product contains monounsaturated fatty acids and bioactive compounds such as polyphenols, carotenoids or tocopherols, with pro healthy effects [2].

The world olive fruit production is $90 \%$ for olive oil and $10 \%$ for table olives [3]. For centuries, olive oil was used as major part of Mediterranean diet, for medicine, and as lamp fuel. Nowadays, olive oil is increasingly consumed for nutritional purposes and in the modern cosmetic industry. In any case, the olive oil industry generates high amounts of waste, particularly during the agricultural phase, i.e., harvesting tasks, and oil production. These byproducts are mostly olive pulp, pits, liquid wastes and leaves [4]. The disposal of these wastes is crucial because of their polluting effects on soil and water [5]. In this sense, over the years, composting has been the most popular technology for the revalorization of olive wastes producing fertilizers [6] or burning residues, although both these practices possess environmental risks. For this reason, recent research studies focus 
on new treatment and revalorization approaches that allow a sustainable recovery of valuable components from olive byproducts [7]. These valuable compounds present in herbal extracts have a long history as traditional remedies in different cultures due to their health benefits, such as antioxidant, anti-inflammatory, antiaging and antimicrobial, which are related to chronic disorders [8]. Therefore, there is a growing interest to reutilize these bioactive phytochemicals in various industrial sectors, such as food, pharmaceutical and cosmetic $[2,4,9]$.

Among these byproducts, leaves, which represent about $5 \%$ of the weight of olives, have been used in folk medicine as remedies for treating diabetes or cardiovascular disorders [10]. Moreover, the scientific community has recently reported the beneficial health effects in humans [11], such as an exploratory randomized controlled trial for testing the beneficial effect of olive leaf tea that showed a significantly decrease in fasting plasma glucose levels [12]. However, further studies are necessary to clarify the candidate compounds responsible for these effects. In this sense, olive leaf composition has been studied by different authors [13-17], reporting the richness in bioactive compounds belonging to phenolic compounds, such as hydroxytyrosol, catechin, rutin, verbascoside, luteolin and oleuropein [18]. These compounds have been associated with antioxidant, anti-inflammatory, antiobesity or chemopreventive effects [15,19-24], among other activities. Specifically, oleuropein, which is formed by elenolic acid, glucose and hydroxytyrosol, acts as a powerful antioxidant at skin level [2]. The aim of this work was to develop powerful ingredients from olive byproducts rich in oleuropein through a combination of generally recognized as safe solvents (water/ethanol) and a feasible and sustainable scaling-up process for cosmetic applications. To this end, industrial olive byproduct extracts were analyzed by high-performance liquid chromatography (HPLC) coupled to quadrupole time of flight (QTOF) mass spectrometry (MS), and their bioactive potential was evaluated through antioxidant and reactive oxygen/nitrogen species scavenging assays as well as enzyme inhibition activities and cell viability effects. This paper proposes a first screening of the possibility of using bioactive compounds from olive fruit and leaves as effective antioxidants with interesting skin health benefits as well as a first barrier against reactive oxygen and nitrogen species related to aging, appraising their potential use for cosmetic purposes. In addition, the skin cell effects of olive byproduct extracts were assessed as an uttermost important preliminary analysis for cosmetics in order to determine the concentrations which show absence of toxicity in keratinocytes.

\section{Materials and Methods}

\subsection{Chemicals and Reagents}

All chemicals were of HPLC-MS grade and used as received. Acetic and formic acid and methanol for HPLC were purchased from Fluka (Sigma-Aldrich, Steinheim, Germany) and Lab-Scan (Gliwice, Sowinskiego, Poland), respectively. For solutions, ultrapure water was obtained with a Milli-Q system Millipore (Bedford, MA, USA), and absolute ethanol was purchased from VWR chemicals (Radnor, PA, USA).

To measure the Total Phenolic Content (TPC) and the antioxidant capacity, the following reagents were provided from the indicated suppliers: AAPH $\left(2,2^{\prime}\right.$-azobis-2methyl-propanimidamide, dihydrochloride), ABTS [2,2'-azinobis (3-ethylbenzothiazoline6-sulphonate)], ferric sulfate, fluorescein, Folin-Ciocalteu reagent, potassium persulfate, TPTZ (2,4,6-tripyridyl-S-triazine) and Trolox (6-hydroxy-2,5,7,8-tetramethylchroman-2carboxylic acid) from Sigma-Aldrich (St. Louis, MO, USA). From Panreac (Barcelona, Spain), gallic acid, dehydrated sodium phosphate, trihydrated sodium acetate, sodium acetate, ferric chloride, hydrochloric acid and sodium carbonate were purchased. To measure Reactive Oxygen/Nitrogen Species (ROS/RNS) scavenging, dihydrorhodamine 123 (DHR), sodium hypochlorite solution with $4 \%$ available chlorine, $\beta$-nicotinamide adenine dinucleotide (NADH), phenazine methosulphate (PMS) and nitroblue tetrazolium chloride (NBT) were purchase from Sigma Aldrich (Steinheim, Germany). Dimethylsulfoxide (DMSO) was obtained from AppliChem (Darmstadt, Germany). 
To measure hyaluronidase and elastase inhibitions, all reagents, hyaluronidase from bovine testes Type I-S, hyaluronic acid as substrate, sodium acetate/phosphate/chloride, bovine serum albumin, buffer HEPES, $\mathrm{NaCl}$, human leucocyte elastase, substrate MeOSucAla-Ala-Pro-Val-pNA and elastatinal, were purchase from Sigma (St. Louis, MO, USA).

For cell viability, human immortalized non-tumorigenic keratinocytes cell line $\mathrm{HaCaT}$ (ethnicity, Caucasian; age, 62 years; gender, male; tissue, skin) was obtained from CLS Cell Lines Service, Germany. Dulbecco's Modified Eagle Medium (DMEM), Fetal Bovine Serum (FBS), GlutaMAX ${ }^{\mathrm{TM}}$, Hank's Balanced Salt Solution (HBSS), non-essential amino acids, penicillin, streptomycin and trypsin-EDTA were obtained from Invitrogen Corporation (Life Technologies, S.A., Madrid, Spain). Trypan blue dye was purchased from Gibco (Thermo Fisher Scientific, Waltham, MA USA). Tissue culture flasks were acquired from Orange Scientific (Braine-1'Alleud, Belgium).

\subsection{Sample Preparation}

Two different oleuropein-enriched extracts from O. europaea fruits and leaves $(\mathrm{O} 20=20 \%$ oleuropein and $\mathrm{O} 30=30 \%$ oleuropein $+10 \%$ triterpenes) were obtained from Natac company (Alcorcón, Madrid, Spain). These extracts were obtained by different process. Briefly, O20 was attained by a first ethanol extraction followed by filtration and concentration steps. After that, a second water extraction was made, followed by filtration, thermal treatment, vacuum drying, milling and standardization steps. O30 was obtained through two extraction processes running in parallel with different filtration and drying methodologies. The two milled final extracts were homogenized and standardized. The commercial extracts were supplied as dry residue then filtered with a $0.2 \mu \mathrm{m}$ sterile filter, evaporated and lyophilized according to the manufacturer's procedure. Both extracts (O20 and O30) were dissolved in ethanol:water $(20: 80 ; v: v)$ at a final concentration of $1 \mathrm{mg} / \mathrm{mL}$ for further experiments, except for the HPLC analysis (extracts were analyzed at a final concentration of $5 \mathrm{mg} / \mathrm{mL}$ ) and cell assays (extracts at $1 \mathrm{mg} / \mathrm{mL}$ were dissolved in the culture medium used); then, extracts were vortexed for $1 \mathrm{~min}$, sonicated for $20 \mathrm{~min}$, centrifuged for $5 \mathrm{~min}$ at $17,000 \times g$ in a Sorvall ST $16 \mathrm{R}$ centrifuge (Thermo Scientific, Leicestershire, UK), filtered through a $0.20 \mathrm{~mm}$ filter and kept at $-20{ }^{\circ} \mathrm{C}$ under light-free conditions until further experiments. Preliminary studies were performed for each assay to investigate the influence of the solvents (water, ethanol and culture medium) in the composition of the extracts.

\subsection{Chromatographic Conditions and Mass Spectrometry Detection}

The ACQUITY UPLC H-Class System (Waters Corp., Milford, MA, USA) was used for the separation of the bioactive compounds from both extracts $(5 \mathrm{mg} / \mathrm{mL})$ at $22{ }^{\circ} \mathrm{C}$ with a Zorbax Eclipse Plus C18 column $(1.8 \mu \mathrm{m}, 150 \times 4.6 \mathrm{~mm})$. The mobile phases were acetic acid $0.5 \%$ (solvent $\mathrm{A}$ ) and methanol (solvent $\mathrm{B}$ ). This multistep linear gradient was applied: $0 \mathrm{~min}, 100 \% \mathrm{~A} ; 5 \mathrm{~min}, 75 \% \mathrm{~A} ; 20 \mathrm{~min} 61 \% \mathrm{~A} ; 30 \mathrm{~min}, 40 \% \mathrm{~A} ; 38 \mathrm{~min}, 0 \% \mathrm{~A} ; 46 \mathrm{~min}, 100 \% \mathrm{~A}$. The initial conditions were maintained for $10 \mathrm{~min}$. The injection volume was $10 \mu \mathrm{L}$. The flow rate used was set at $0.4 \mathrm{~mL} / \mathrm{min}$.

The HPLC analysis was coupled to QTOF/MS (Synapt G2, Waters Corp., Milford, MA, USA). The determination of the compounds was carried out using an electrospray source operating in negative ionization mode under the following conditions: MS acquisition was performed using two parallel scan functions by rapid switching, in which one scan was operated at low collision energy in the gas cell $(4 \mathrm{eV})$ and the other at an elevated collision energy (MSE energy linear ramp: from 20 to $60 \mathrm{eV}$ ); desolvation gas flow $=700 \mathrm{~L} \mathrm{~h}^{-1}$, desolvation temperature $=500{ }^{\circ} \mathrm{C}$, cone gas flow $=50 \mathrm{~L} \mathrm{~h}^{-1}$, source temperature $=100{ }^{\circ} \mathrm{C}$, capillary voltage $=2.2 \mathrm{kV}$, cone voltage $=30 \mathrm{~V}$ and collision energy $=20 \mathrm{eV}$. Full-scan mode was used $(m / z=50-1200)$. Scan duration was $0.1 \mathrm{~s}$, and resolution was 20,000 FWHM. The MS data were processed through the open-source software MZmine. 


\subsection{Total Phenolic Content and Antioxidant Capacity Assays}

The Folin-Ciocalteu method was carried out to measure the total phenolic content (TPC) as firstly validated by Singleton and Rossi [25], with minor modifications. This assay was directly performed in 96-well polystyrene microplates. Briefly, $30 \mu \mathrm{L}$ of extracts $(125 \mu \mathrm{g} / \mathrm{mL})$ was mixed with $150 \mu \mathrm{L}$ of Folin-Ciocalteu's reagent $(1: 10, v / v)$ and $120 \mu \mathrm{L}$ of $7.5 \%(w / v) \mathrm{Na}_{2} \mathrm{CO}_{3}$ solution. The microplate was incubated at $45{ }^{\circ} \mathrm{C}$ for $15 \mathrm{~min}$ in a Synergy Mx Monochromator-Based Multimode Microplate reader (Bio-Tek Instruments Inc., Winooski, VT, USA) and then left to stand in the dark for $30 \mathrm{~min}$, at room temperature. Then, the absorbance was measured at $765 \mathrm{~nm}$, and TPC was calculated based on the calibration curves of gallic acid and expressed as mg of gallic acid equivalents (GAE)/g of dry extract. FRAP assay was performed according to the procedure described by Benzie and Strain [26], with slight modifications. An aliquot $(40 \mu \mathrm{L})$ of extracts $(250 \mu \mathrm{g} / \mathrm{mL})$ was added to a 96-well microplate, along with $250 \mu \mathrm{L}$ of FRAP reagent (composed by 10 parts of $300 \mathrm{mM}$ sodium acetate buffer at $\mathrm{pH} 3.6,1$ part of $10 \mathrm{mM}$ TPTZ solution and 1 part of $20 \mathrm{mM} \mathrm{FeCl}_{3} 6 \mathrm{H}_{2} \mathrm{O}$ solution). Ferrous sulphate was employed as standard $(12.5-200 \mu \mathrm{M})$. After incubating the microplate at $37^{\circ} \mathrm{C}$ for $10 \mathrm{~min}$, the absorbance was recorded at $593 \mathrm{~nm}$ for $4 \mathrm{~min}$. Results were expressed as $\mathrm{mmol}$ of ferrous sulphate equivalents $\left(\mathrm{FeSO}_{4}\right) / \mathrm{g}$ dry extract. The TEAC was determined by ABTS radical scavenging capacity assay following the procedure described by Miller et al. [27] with minor alterations. ABTS radical cation $\left(\mathrm{ABTS}^{\bullet+}\right.$ ) working solution was prepared by adding ABTS ${ }^{\bullet+}$ stock solution to $2.45 \mathrm{mM}$ potassium persulfate, and the final mixture was kept in the dark at room temperature, for 12 to $24 \mathrm{~h}$. Prior to use, the $\mathrm{ABTS}^{\bullet+}$ working solution was diluted with ultrapure water until reaching an absorbance of $0.700( \pm 0.02)$ at $734 \mathrm{~nm}$. In a nutshell, $300 \mu \mathrm{L}$ of $\mathrm{ABTS}^{\bullet+}$ solution and $30 \mu \mathrm{L}$ of extracts $(250 \mu \mathrm{g} / \mathrm{mL})$ or standard were mixed for $45 \mathrm{~s}$, and the absorbance was measured after $5 \mathrm{~min}$ at $734 \mathrm{~nm}$. Trolox $(0.5-30 \mu \mathrm{M})$ was used as standard to plot a calibration curve. TEAC results were expressed as mmol of Trolox equivalents/g dry extract. The ORAC assay was performed to assess the capacity of the extracts to scavenge peroxyl radicals following the methodology described by Ou et al. [28] and modified by Laporta et al. [29]. A $56 \mathrm{nM}$ fluorescein solution was prepared and kept for at least $30 \mathrm{~min}$ at $37^{\circ} \mathrm{C}$ before use. Briefly, the reaction mixture (final volume of $210 \mu \mathrm{L}$ ) contained $40 \mathrm{nM}$

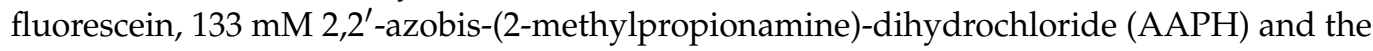
tested concentrations of extracts $(125 \mu \mathrm{g} / \mathrm{mL})$ or Trolox $(0.5-15 \mu \mathrm{M})$. Trolox was employed as standard to draw the calibration curve. All solutions were diluted in buffer solution consisting of $0.2 \mathrm{M} \mathrm{NaH}_{2} \mathrm{PO}_{4}$ and $0.2 \mathrm{M} \mathrm{Na}_{2} \mathrm{HPO}_{4}(20: 80, v / v)$ at $\mathrm{pH}$ 7.4. The microplate was incubated at $37^{\circ} \mathrm{C}$, and the fluorescence was read at $520 \mathrm{~nm}$ (excitation wavelength at $485 \mathrm{~nm}$ ) for $2 \mathrm{~h}$. The results were expressed as mmol of Trolox equivalents/g dry extract. Three independent experiments were carried out for each assay.

\subsection{Reactive Oxygen/Nitrogen Species Scavenging}

The extracts and positive controls (gallic acid and catechin) were previously dissolved in phosphate buffer used for each procedure. These methods were performed in a Synergy HT Microplate Reader (BioTek Instruments, Inc., Winooski, VT, USA). Three independent experiments using six concentrations, in duplicate, were carried out for each assay. Results were calculated from the curves of inhibition percentage versus antioxidant concentration using the GraphPad Prism 7 software (GraphPad, La Jolla, CA, USA). Prior to the assays, the absorption of the extract was studied at the proper wavelengths for each method. The methods for superoxide radical scavenging activity, hypochlorous acid scavenging assay and nitric oxide scavenging assay were carried out following the reported literature [30]. Results were expressed as the inhibition in $\mathrm{IC}_{50}$. The $\mathrm{IC}_{50}$ values were automatically calculated by GraphPad Prism 7 software.

\subsection{Enzyme Inhibitions}

Hyaluronidase and elastase inhibitory assays were performed following the method describe by Nema et al., 2011 and 2013 [31,32]. Briefly, for hyaluronidase, the assay medium 
consisting of hyaluronidase $(1.50 \mathrm{U})$ in $100 \mathrm{~mL}, 20 \mathrm{mM}$ sodium phosphate buffer ( $\mathrm{pH} 7.0$ ) with $77 \mathrm{mM}$ sodium chloride solution and $0.01 \%$ bovine serum albumin (BSA) was preincubated with $5 \mathrm{~mL}$ of the extracts for $10 \mathrm{~min}$ at $37^{\circ} \mathrm{C}$. Then, the assay was started by adding hyaluronic acid to the mixture. This was incubated for $45 \mathrm{~min}$ at $37^{\circ} \mathrm{C}$. The undigested hyaluronic acid was precipitated, and finally, the absorbance was measured at $600 \mathrm{~nm}$. For elastase, the amount of released $p$-nitroaniline, which was hydrolyzed from the substrate, MeOSuc-Ala-Ala-Pro-Val-pNa, by elastase, was read with a maximum absorbance at $405 \mathrm{~nm}$. In brief, MeOSuc-Ala-Ala-Pro-Val-pNa was prepared in buffer ( $\mathrm{pH} 8.0$ ), and this solution was added to the samples. The solutions were vortexed and pre-incubated at $37^{\circ} \mathrm{C}$ for $10 \mathrm{~min}$ before an elastase solution was added. After that, they were incubated at $37^{\circ} \mathrm{C}$ for $30 \mathrm{~min}$, and the absorbance was measured at $405 \mathrm{~nm}$. All measurements were made in triplicate.

\subsection{Cell Viability}

The cell viability assay was carried out according to the method described by Lameirão et al. [33]. HaCaT cells were individually maintained in Dulbecco's modified Eagle's medium (DMEM) with GlutaMAX ${ }^{\mathrm{TM}}-\mathrm{I}, 10 \%$ inactivated fetal calf serum, $100 \mathrm{U} / \mathrm{mL}$ penicillin, $100 \mathrm{mG} / \mathrm{mL}$ streptomycin and $0.25 \mathrm{mG} / \mathrm{mL}$ amphotericin $\mathrm{B}$, in a $5 \% \mathrm{CO}_{2}$ environment at $37^{\circ} \mathrm{C}$ (CellCulture ${ }^{\circledR} \mathrm{CO}_{2}$ Incubator, ESCO GB Ltd., UK). The number of viable cells was periodically assessed by the trypan blue exclusion assay. Keratinocytes (HaCaT cell line; passage 18-21) were exposed to different concentrations $(0.1-1000 \mu \mathrm{g} / \mathrm{mL})$ of extract for $24 \mathrm{~h}$ at $37^{\circ} \mathrm{C}$ and in a water saturated atmosphere with $5 \%$ $\mathrm{CO}_{2}$ using an incubator. Following the supplier instructions, the 3-(4,5-dimethylthiazol2-yl)-5-(3-carboxymethoxyphenyl)-2-(4-sulfophenyl)-2H-tetrazolium (MTT) assay was performed to estimate the intestinal cells' viability by the determination of the number of viable cells through a colorimetric reaction. Briefly, cells were straightly placed in 96-well microplate (density of $25 \times 10^{3}$ cells / well) and incubated at $37^{\circ} \mathrm{C}$ for $24 \mathrm{~h}$. Afterwards, cells were exposed to different concentrations of $\mathrm{O} 20$ and $\mathrm{O} 30$ extracts, positive control $(1 \%(v / v)$ Triton X-100) and negative control (DMEM) for $24 \mathrm{~h}$. After the supernatant removal, the MTT was added to each well, and the microplate was incubated at $37{ }^{\circ} \mathrm{C}$ for $3 \mathrm{~h}$ to promote the development of formazan crystals. Then, the MTT solution was removed, and the blue formazan crystals were eluted with DMSO. Absorbance was read at $570 \mathrm{~nm}$ with a background subtraction at $690 \mathrm{~nm}$.

\subsection{Statistical Analysis}

All experiments were carried out at least in triplicate. The results were presented as mean \pm standard deviation of at least three independent experiments. IBM SPSS Statistics 24.0 software (SPSS Inc., Chicago, IL, USA) was used for the statistical analyses of data. The differences between samples were investigated by one-way ANOVA, and post hoc comparisons of the means were performed with Tukey's HSD test. In all cases, a denoting significance was accepted for $p<0.05$. Regarding ROS and RNS scavenging assays, at least three independent experiments using six concentrations, in duplicate, were performed. Results were determined from the curves of inhibition percentage versus antioxidant concentration using GraphPad Prism 7 software (GraphPad, La Jolla, CA, USA).

\section{Results and Discussion}

\subsection{Phenolic Profile of Olive Byproduct Extracts by HPLC-QTOF}

Since it is important to have a better interpretation of the diversity of available phytochemicals contained in the bioactive ingredients from industrial olive byproducts, both O20 and O30 extracts were comprehensively characterized by HPLC-QTOF in order to analyze the polar bioactive fraction. The analytical platform provided two base peak chromatograms (BPC) that are shown in Figure 1. The characterized compounds are summarized in Table 1, numbered according to their elution order. This table includes retention times, proposed compound, $m / z$, molecular formula, MS/MS fragments and the presence 
of the compound in each extract. The identification of each compound was carried out by interpreting the accurate mass spectra information provided by MS and MS/MS and information previously reported in the literature. In this sense, a total of 49 compounds were detected, among which 28 were found in both extracts. This fact could be due to the differences in the extract production or even to the detection limits in the chromatographic analysis above all when the extracts are enriched in some specific compounds.
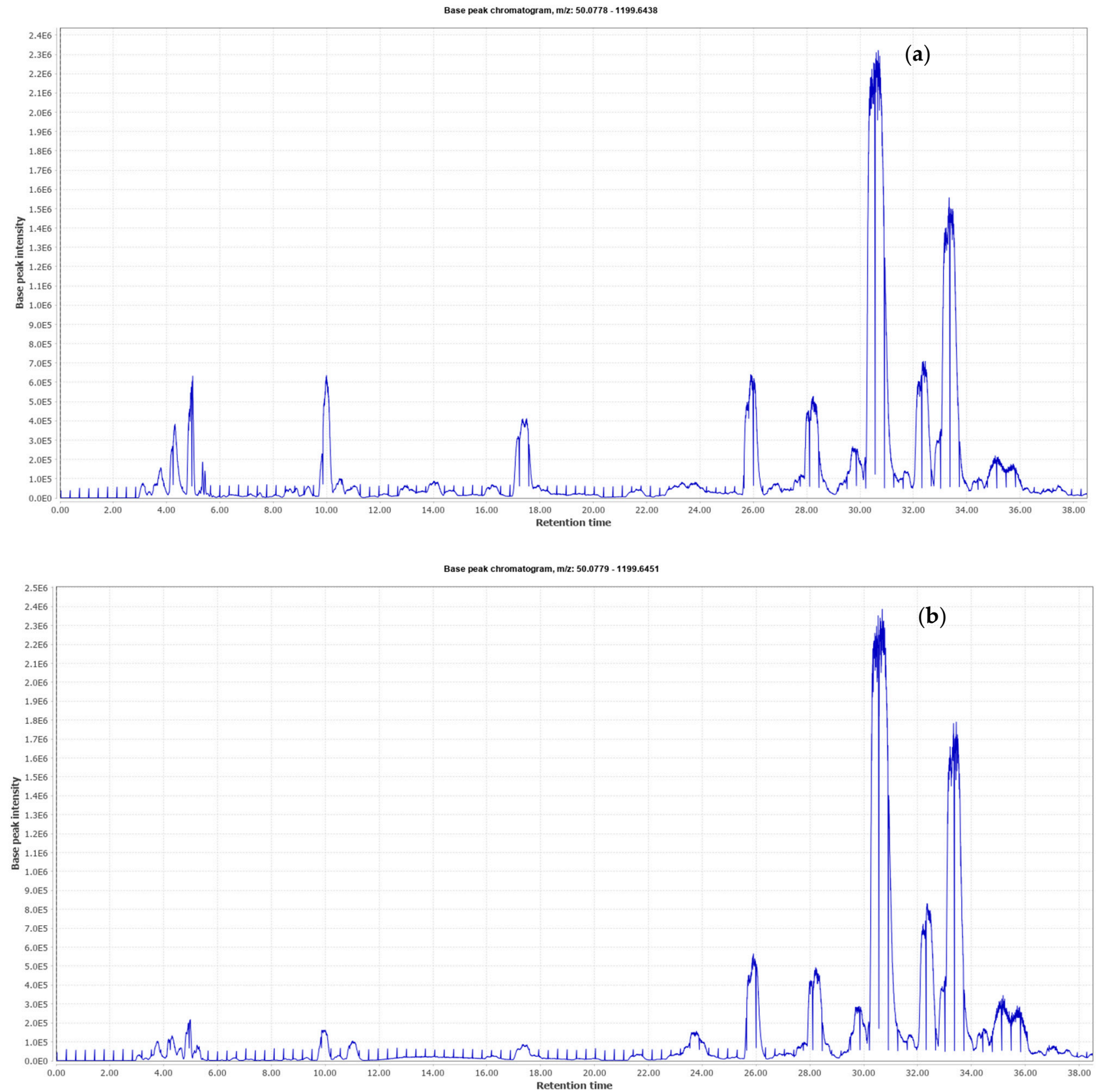

Figure 1. Base peak chromatograms of $\mathrm{O} 20$ (a) and $\mathrm{O} 30$ (b) olive byproduct extracts obtained by high performance liquid chromatography coupled to mass spectrometry. 
Table 1. Chemical characterization of bioactive compounds detected in olive byproduct extracts by HPLC-QTOF.

\begin{tabular}{|c|c|c|c|c|c|c|c|}
\hline $\begin{array}{l}\text { Compound } \\
\text { Number }\end{array}$ & Proposed Compound & RT & $m / z$ & $\begin{array}{l}\text { Molecular } \\
\text { Formula }\end{array}$ & MS/MS & $\mathrm{O} 20$ & O30 \\
\hline 1 & Gluconic acid & 3.8 & 195 & $\mathrm{C} 6 \mathrm{H} 12 \mathrm{O} 7$ & 129 & $x$ & $x$ \\
\hline 2 & Sucrose & 4.98 & 341 & $\mathrm{C} 12 \mathrm{H} 22 \mathrm{O} 11$ & 179 & $x$ & $x$ \\
\hline 3 & Citric acid & 6.49 & 191 & $\mathrm{C} 6 \mathrm{H} 8 \mathrm{O} 7$ & 111 & $x$ & \\
\hline 4 & Vanillin & 6.63 & 151 & $\mathrm{C} 8 \mathrm{H} 8 \mathrm{O} 3$ & - & & $x$ \\
\hline 5 & Methyl xylobioside & 7.19 & 295 & $\mathrm{C} 11 \mathrm{H} 20 \mathrm{O} 9$ & $181,151,191$ & $x$ & \\
\hline 6 & Methyl gallate glucoside & 7.51 & 563 & $\mathrm{C} 14 \mathrm{H} 18 \mathrm{O} 10$ & 277 & $x$ & \\
\hline 7 & Leonuriside & 8.14 & 331 & C14H20O9 & 169,139 & $x$ & \\
\hline 8 & Methyl xylobioside & 8.65 & 295 & $\mathrm{C} 11 \mathrm{H} 20 \mathrm{O} 9$ & 153 & $x$ & \\
\hline 9 & Oleoside Isomer 1 & 8.88 & 389 & $\mathrm{C} 16 \mathrm{H} 22 \mathrm{O} 11$ & 137,295 & $x$ & $x$ \\
\hline 10 & Loganic acid & 9.32 & 375 & $\mathrm{C} 16 \mathrm{H} 24 \mathrm{O} 10$ & $315,213,209$ & $x$ & $x$ \\
\hline 11 & Oleoside Isomer 2 & 10.11 & 389 & C16H22O11 & 183,121 & $X$ & $X$ \\
\hline 12 & Aralidioside & 10.59 & 447 & $\mathrm{C} 18 \mathrm{H} 24 \mathrm{O} 13$ & 153 & $x$ & $x$ \\
\hline 13 & Hydroxytyrosol & 11.06 & 153 & $\mathrm{C} 8 \mathrm{H} 10 \mathrm{O} 3$ & 123,135 & $x$ & $x$ \\
\hline 14 & Taxifolin & 11.84 & 303 & $\mathrm{C} 15 \mathrm{H} 12 \mathrm{O} 7$ & $161,179,153$ & $x$ & \\
\hline 15 & Iridoid glicoside derivative & 12.26 & 553 & $\mathrm{C} 22 \mathrm{H} 34 \mathrm{O} 16$ & 181,411 & $x$ & \\
\hline 16 & Allobetonicoside & 12.95 & 505 & $\mathrm{C} 21 \mathrm{H} 30 \mathrm{O} 14$ & 161 & $x$ & \\
\hline 17 & Eriobioside & 13.23 & 567 & $\mathrm{C} 23 \mathrm{H} 36 \mathrm{O} 16$ & $\begin{array}{c}181,223,161,341,403 \\
505\end{array}$ & $x$ & \\
\hline 18 & Elenolic acid glucoside Isomer 1 & 13.64 & 403 & C17H24O11 & 161 & $X$ & $X$ \\
\hline 19 & Elenolic acid glucoside Isomer 2 & 14.04 & 403 & $\mathrm{C} 17 \mathrm{H} 24 \mathrm{O} 11$ & 161 & $x$ & \\
\hline 20 & Loganin & 15.65 & 389 & $\mathrm{C} 17 \mathrm{H} 26 \mathrm{O} 10$ & 327,267 & $x$ & \\
\hline 21 & Acetylbarlerin & 16.25 & 489 & C21H30O13 & $145,163,327$ & $x$ & $x$ \\
\hline 22 & Oleoside Isomer 3 & 17.46 & 389 & $\mathrm{C} 16 \mathrm{H} 22 \mathrm{O} 11$ & 345 & $x$ & $X$ \\
\hline 23 & Benzyl primeveroside & 17.98 & 401 & C18H26O10 & 223 & $x$ & $x$ \\
\hline 24 & Cinnamoside & 18.21 & 517 & C24H38O12 & $387,459,409,175$ & $x$ & $x$ \\
\hline 25 & Depressine & 19.45 & 687 & $\mathrm{C} 25 \mathrm{H} 30 \mathrm{O} 13$ & 525,161 & & $X$ \\
\hline 26 & Paniculatin & 20.06 & 593 & С27H30O15 & $353,383,473,175$ & & $x$ \\
\hline 27 & Kaempferol diglucoside & 21.77 & 609 & C27H30O16 & $447,285,197,153$ & $x$ & $x$ \\
\hline 28 & $\begin{array}{c}\text { Phenethyl primeveroside } \\
\text { Isomer } 1\end{array}$ & 23.41 & 415 & $\mathrm{C} 19 \mathrm{H} 28 \mathrm{O} 10$ & $151,175,223$ & $x$ & \\
\hline 29 & Hydroxyoleuropein Isomer 1 & 23.78 & 555 & $\mathrm{C} 25 \mathrm{H} 32 \mathrm{O} 14$ & 151 & & $X$ \\
\hline 30 & $\begin{array}{c}\text { Phenethyl primeveroside } \\
\text { Isomer } 2\end{array}$ & 23.87 & 415 & C19H28O10 & 151,123 & $x$ & $x$ \\
\hline 31 & Oleuropein glucoside Isomer 1 & 25.35 & 701 & $\mathrm{C} 31 \mathrm{H} 42 \mathrm{O} 18$ & $315,285,447,337$ & $x$ & $X$ \\
\hline 32 & Verbascoside & 26.1 & 623 & $\mathrm{C} 29 \mathrm{H} 36 \mathrm{O} 15$ & 161,461 & $x$ & $x$ \\
\hline 33 & Syringaresinol & 26.87 & 417 & $\mathrm{C} 22 \mathrm{H} 26 \mathrm{O} 8$ & $181,166,387$ & & $x$ \\
\hline 34 & Hydroxyoleuropein Isomer 2 & 26.93 & 555 & $\mathrm{C} 25 \mathrm{H} 32 \mathrm{O} 14$ & $161,417,181$ & $x$ & $x$ \\
\hline 35 & Calceolarioside A & 27.2 & 477 & $\mathrm{C} 23 \mathrm{H} 26 \mathrm{O} 11$ & 161 & & $x$ \\
\hline 36 & Kaempferol rutinoside & 27.88 & 593 & C27H30O15 & 285 & $x$ & $x$ \\
\hline 37 & Luteolin glucoside & 28.2 & 447 & $\mathrm{C} 21 \mathrm{H} 20 \mathrm{O} 11$ & 285 & $X$ & $x$ \\
\hline 38 & Oleuropein glucoside Isomer 2 & 29.31 & 701 & $\mathrm{C} 31 \mathrm{H} 42 \mathrm{O} 18$ & $609,300,539,269$ & $x$ & $X$ \\
\hline 39 & Methoxyoleuropein & 29.74 & 569 & $\mathrm{C} 26 \mathrm{H} 34 \mathrm{O} 14$ & $151,223,537,403,553$ & $X$ & $x$ \\
\hline 40 & Oleuropein Isomer 1 & 30.36 & 539 & $\mathrm{C} 25 \mathrm{H} 32 \mathrm{O} 13$ & $307,275,149,377$ & $X$ & $X$ \\
\hline
\end{tabular}


Table 1. Cont.

\begin{tabular}{|c|c|c|c|c|c|c|c|}
\hline $\begin{array}{l}\text { Compound } \\
\text { Number }\end{array}$ & Proposed Compound & RT & $m / z$ & $\begin{array}{l}\text { Molecular } \\
\text { Formula }\end{array}$ & MS/MS & $\mathbf{O} 20$ & O30 \\
\hline 41 & Luteolin glucoside & 31.85 & 447 & $\mathrm{C} 21 \mathrm{H} 20 \mathrm{O} 11$ & 285 & $x$ & $x$ \\
\hline 42 & Oleuropein Isomer 2 & 32.38 & 539 & $\mathrm{C} 25 \mathrm{H} 32 \mathrm{O} 13$ & $307,275,403,149,377$ & $x$ & $x$ \\
\hline 43 & Ligstroside & 32.98 & 523 & $\mathrm{C} 25 \mathrm{H} 32 \mathrm{O} 12$ & $291,259,361$ & $x$ & $x$ \\
\hline 44 & Oleuropein Isomer 3 & 33.4 & 539 & $\mathrm{C} 25 \mathrm{H} 32 \mathrm{O} 13$ & $307,275,121,223$ & $x$ & $x$ \\
\hline 45 & Oleuropein Isomer 4 & 34.45 & 539 & $\mathrm{C} 25 \mathrm{H} 32 \mathrm{O} 13$ & $307,275,153,377$ & $x$ & $x$ \\
\hline 46 & $\begin{array}{c}\text { Oleoeuropein aglycone Isomer } \\
1\end{array}$ & 35.16 & 377 & C19H22O8 & $307,149,275$ & $X$ & $X$ \\
\hline 47 & $\begin{array}{c}\text { Oleoeuropein aglycone Isomer } \\
2\end{array}$ & 35.79 & 377 & C19H22O8 & $307,149,139,11,275$ & & $X$ \\
\hline 48 & Oleuropein derivative & 36.53 & 763 & $\mathrm{C} 36 \mathrm{H} 44 \mathrm{O} 18$ & 539,307 & & $x$ \\
\hline 49 & $\begin{array}{c}\text { Oleoeuropein aglycone Isomer } \\
3\end{array}$ & 37.07 & 377 & $\mathrm{C} 19 \mathrm{H} 22 \mathrm{O} 8$ & 307,275 & & $x$ \\
\hline
\end{tabular}

MS/MS: tandem mass spectrometry.

All compounds were classified into four major categories, oleuropein and its related compounds, iridoids, flavonoids and other compounds.

\subsubsection{Oleuropein and Its Related Compounds}

It is known that the most abundant group of compounds in olive leaves is secoiridoids, mainly oleuropein $(40,42,44,45)$ and its derivatives, but also the simple phenol hydroxytyrosol (13), a precursor of oleuropein, and verbascoside (32), a conjugated glucoside of hydroxytyrosol and caffeic acid [34]. It is worth noting that both olive byproduct extracts $(\mathrm{O} 20$ and $\mathrm{O} 30)$ were attained with the purpose of developing oleuropein-enriched ingredients due to its reported antioxidant, anti-inflammatory, antimicrobial or antiaging effects [35]. For this reason, compounds 40, 42 and 44 (oleuropein isomers 1, 2 and 3) are the most abundant peaks. The presence of these isomers is due to the oleuropein isomer present that may have a glycosylation position distinct from hydroxytyrosol. Similarly to oleuropein, oleuropein derivatives were also detected, such as different isomers of hydroxyoleuropein $(29,34)$, oleuropein glucoside $(31,38)$ and oleuropein aglycone $(46,47,49)$. Other derivatives, such as methoxyoleuropein (39) and another new related compound (48), were also identified. The last one detected at $m / z 763$ and molecular formula $\mathrm{C}_{36} \mathrm{H}_{44} \mathrm{O}_{18}$, which gave an MS/MS spectrum with main fragment ions at $\mathrm{m} / \mathrm{z} 539$ and 307 , corresponded to oleuropein and its major product ion, respectively. To the best of our knowledge, this is the first time that this derivative has been reported, although a similar compound was previously described at $m / z 864$ by Cardoso et al. [36]. In addition, among secoiridoids, ligstroside (43) was also detected in both extracts as well as two isomers of elenolic acid glucoside $(\mathbf{1 8}, \mathbf{1 9})$. In a nutshell, tyrosol, hydroxytyrosol and oleuropein have been suggested as possible cosmetic ingredients due to their antioxidant and anti-inflammatory properties and claims of antiaging and hydration effects [37].

\subsubsection{Iridoids}

This group comprises a wide number of monoterpenes and glucoside derivatives, whose structure may be derived from iridane. In addition, iridoids are the precursors of secoiridoids by opening the pentacyclic ring [38]. In the analyzed extracts, eight compounds were detected; among them, only three iridoids were found in both extracts corresponding to loganic acid (10); aralidioside (12), which has been reported in woody perennials for showing cardioprotective effects [39]; and acetylbarlein (21). These last two iridoids have been described for the first time in olive leaves in this work. 
Moreover, a group of iridoid glucoside derivatives was only found in $\mathrm{O} 20$ extracts. These compounds were tentatively identified for the first time in olive leaves as eriobioside (17), allobetonicoside (16) and other related compound (15) with a shared fragmentation pattern at $m / z 181$ and 161 as main fragments (Figure 2). Loganin (20) was also only detected in O20. However, a secologanol derivative from Gentiana depressa [40] was distinguished at $\mathrm{m} / \mathrm{z} 687$ and tentatively identified as depressine (25).

In conclusion, iridoids are interesting bioactive compounds largely used in skin disorders mostly due to their anti-inflammatory and antioxidant properties [41,42].

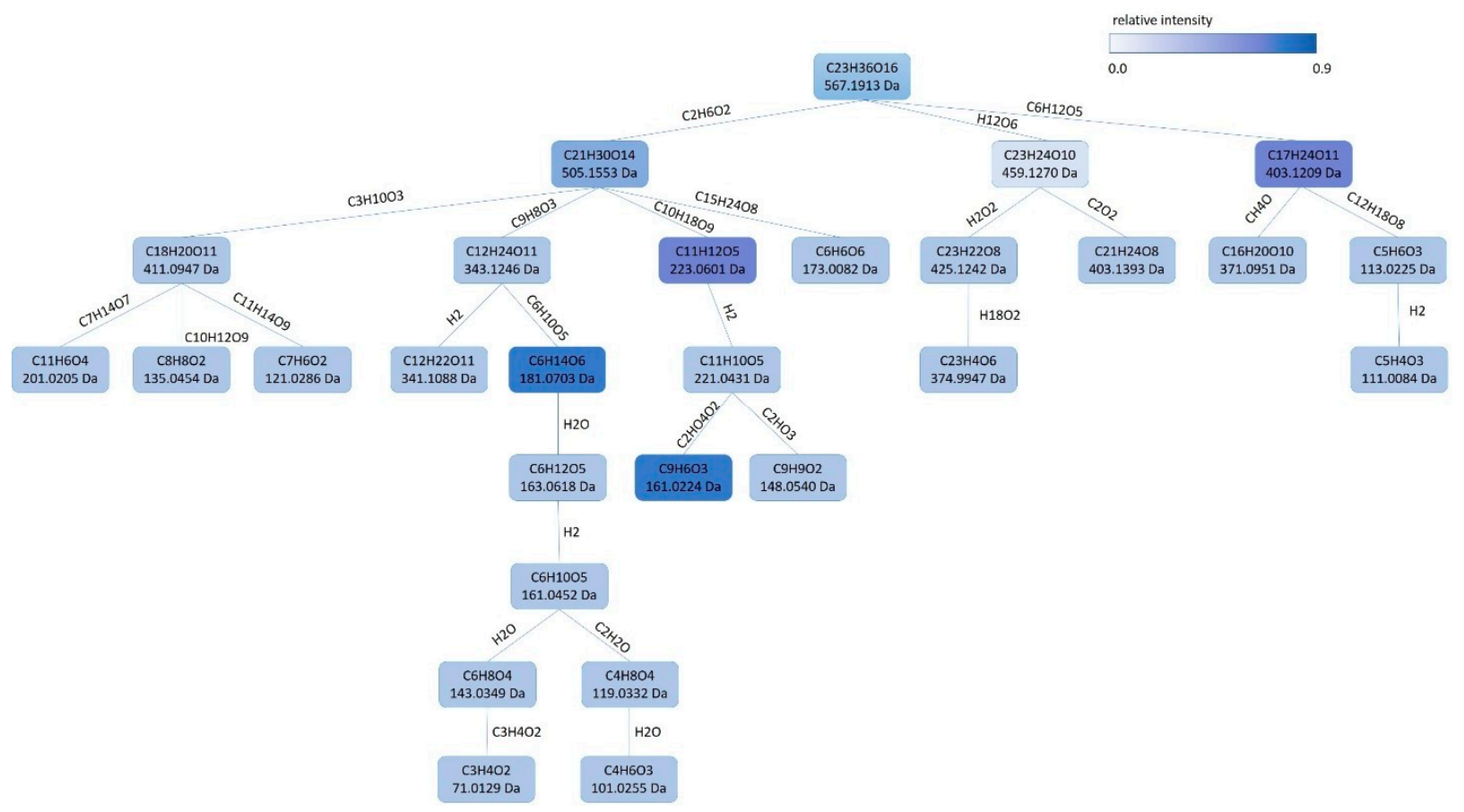

Figure 2. Fragmentation pattern tree from Sirius [43] of eribioside (17) found in O20 olive byproduct extract with shared MS ion spectrum with allobetonicoside (16) and another related compound (15).

\subsubsection{Flavonoids}

Flavonoids are among the main components of olive leaves presenting several biological properties [21]. Six compounds belonging to a flavonoid class were tentatively identified in $\mathrm{O} 20$ and $\mathrm{O} 30$ extracts, namely, taxifolin (14); paniculin (26), an isoflavone substituted by hydroxy groups that has been firstly reported in this work; two flavonols (kaempferol diglucoside (27) and rutinose (36)); and two flavones that were luteolin glucoside isomers (37 and 41).

\subsubsection{Other Compounds}

Among this heterogeneous group, it was possible to detect organic acids, such as gluconic (1) and citric (3) acid, and different sugars $(2,5,8)$. Moreover, simple phenols, namely, vanillin (4), which is commonly identified in olive leaves [44]; methylgallate glucoside (6); and the phenolic glycoside leunoriside A (7) were also characterized. The last one, leunoriside A, was reported as a stronger antioxidant than 3-tert-butyl-4-hydroxyanisole in Leonurus japonicus [45] and in the peel of chufa (Eleocharis dulcis) [46]. In addition, three isomers of oleoside $(\mathbf{9}, \mathbf{1 1}$ and 22) were detected at $\mathrm{m} / \mathrm{z} 389$. These compounds are present in a high amount in olive flowers [14].

On the other hand, cinnamoside (24), a terpene glycoside that was described in Robusta coffee [47], was also detected in O20 and O30 extracts. Moreover, three o-glycosyl compounds were detected at $m / z 401(23)$ and $415(28,30)$. Among these primeveroside derivatives, $\mathbf{2 8}$ and $\mathbf{3 0}$ corresponding to phenetyl primeveroside isomers, these compounds 
have been previously found in olive leaves and reported for their capacity to inhibit AMP-activated protein kinase (AMPK) activity, an important regulator of cellular energy homeostasis, in a hypertrophic adipocyte model [23]. Finally, lignan syringaresinol (33) and the phenylpropanoid calceolarioside A (35) were also identified, the latter having been previously reported in olive leaves, although with other mass spectra data [23]. In this sense, this compound has also been identified in Globularia orientalis [48] with the same $\mathrm{m} / \mathrm{z}$, molecular formula and MS/MS spectrum that were obtained in O30 extract.

Overall, olive byproducts are excellent sources of bioactive compounds, particularly oleuropein and its derivatives, iridoids and flavonoids, with promising application in the cosmetic field due to interesting biological activities [49]. The valorization of olive wastes for the cosmetic industry will allow us to (i) recover bioactive compounds and use them to design high added value products with skin health effects; (ii) generate an additional economic resource for agro-industries; and (iii) decrease the environmental impacts of these agro-wastes [37].

\subsection{Cosmetic Potential of Industrial Olive Byproduct-Enriched Extracts}

\subsubsection{Total Phenolic Content and Antioxidant Activity}

The antioxidant properties of phenolic compounds from plant sources have been widely reported in the literature $[13,14,16,34]$. Polyphenols are plant secondary metabolites that act as antioxidants and UV blockers, providing remarkable skin health effects and attenuating the effects of skin aging through the mitigation of the biochemical consequences of oxidation [2,37]. Antioxidants are innovative ingredients for skin care formulations due to their antioxidant and antimicrobial activities, protective effects from UV-mediated damages and inhibition of dermal proteinases [2,37]. Several plant-derived extracts have been employed in cosmetic products already marketed on a large scale [37]. The most common approaches to investigating the content and the antioxidant and antiradical potentials of phenolic compounds are by different in vitro methodologies, such as FolinCiocalteu and FRAP, TEAC or ORAC assays, respectively [50]. In this sense, Table 2 shows the obtained value for both olive byproduct extracts of TPC and antioxidant/antiradical activity assays. According to the obtained data, there are no significant differences in the $t$-test, but $\mathrm{O} 30$ achieved the highest values in all experiments. This fact could be related to the high content of oleuropein, which has been reported to be a potent antioxidant compound [35].

Table 2. Total phenolic content and antioxidant capacity of both olive byproduct extracts.

\begin{tabular}{ccccc}
\hline & TPC $^{\mathbf{a}}$ & FRAP $^{\mathbf{b}}$ & TEAC $^{\mathbf{c}}$ & ORAC $^{\mathbf{c}}$ \\
\hline O20 & $193 \pm 9$ & $1.66 \pm 0.03$ & $0.80 \pm 0.05$ & $3.91 \pm 0.01$ \\
\hline O30 & $217 \pm 3$ & $1.90 \pm 0.06$ & $0.95 \pm 0.02$ & $3.99 \pm 0.08$ \\
\hline
\end{tabular}

${ }^{\mathrm{a}} \mathrm{mg} \mathrm{GAE} / \mathrm{g}$ dry extract, ${ }^{\mathrm{b}} \mathrm{mmol}$ eq. $\mathrm{FeSO}_{4} / \mathrm{g}$ dry extract, ${ }^{\mathrm{c}} \mathrm{mmol}$ eq. Trolox/g dry extract. Values are expressed as mean \pm standard deviation.

It is important to remark that both extracts demonstrated higher TPC and stronger antioxidant potential than other extracts previously reported in the literature [34,51-53]. The TPC of O20 and O30 extracts was 193 and 217 mg GAE/g dry extract. For example, olive leaf extracts from different cultivars were screened by Özcan et al. to evaluate their TPC, achieving values from 73.05 to $144.19 \mathrm{mg} \mathrm{GAE} / \mathrm{g}$ dry extract, which are lower than those obtained in the present study [34]. Similarly, olive leaf extracts from Greek cultivars demonstrated lower TPC values by Folin-Ciocalteu methodology for all studied solvents (from 0.47 to $24 \mathrm{mg}$ gallic acid/g dry extract) [54]. Khounani et al. also reported lower TPC for olive leaf methanolic extract ( $92.20 \mathrm{mg} \mathrm{GAE} / \mathrm{g}$ dry extract) [55]. In addition, although optimized conditions of ultrasound assisted extraction of bioactive compounds from olive leaves were also evaluated in Greek cultivars, the best TPC value was attained at $37.44 \mathrm{mg}$ gallic acid/g dry extract [51], considerably lower than the present results. 
Comparing to olive pomace from different cultivars (5.37-9.26 g GAE/kg dry extract), the olive by-product extracts analyzed in this study also had a higher TPC [56].

Regarding antioxidant capacity, both extracts showed higher values than those reported in literature [52,53]. The TEAC values were, respectively, 0.80 and $0.95 \mathrm{mmol}$ eq. Trolox/g dry extract for O20 and O30 extracts. For example, a commercial micronized powdered olive leaf extract provided by Folhas de Oliva ${ }^{\circledR}$ (Brazil) was used to evaluate in vitro antiradical action by TEAC assay, giving $0.592 \mathrm{mmol}$ eq. Trolox/g dry extract $[52,53]$. Lower TEAC results were obtained for aqueous and $70 \%$ ethanol extracts from olive leaves (300-700 $\mu \mathrm{mol}$ eq. Trolox/g dry extract) [57]. Other genotypes from Turkey displayed similar $\mathrm{ABTS}^{\bullet+}$ scavenging activity to that reported in Table 2, presenting a strong correlation between TEAC values and oleuropein content [53]. The results of ORAC assay were 3.91 and $3.99 \mathrm{mmol}$ eq. Trolox/g dry extract. Additionally, Bermúdez-Oria et al. extracted pectin polysaccharides from olive pomace by hydrothermal treatment using different extraction temperatures $\left(80-160^{\circ} \mathrm{C}\right)$ [58]. Lower outcomes were reported for all extracts (50-400 $\mu \mathrm{mol}$ eq. Trolox/g dry extract) compared to the present study. Regarding FRAP assay, the results were 1.66 and $1.90 \mathrm{mmol}$ eq. $\mathrm{FeSO}_{4} / \mathrm{g}$ dry extract for $\mathrm{O} 20$ and O30 extracts, respectively. Nunes et al. reported minor ferric reducing antioxidant power for olive pomace aqueous extract (66.38-101.51 $\mathrm{g} \mathrm{FeSO}_{4} / \mathrm{kg}$ dry extract) compared to the present study [56]. All these results support the potential of O20 and O30 extracts as antioxidant sources for cosmetic applications.

\subsubsection{Reactive Oxygen/Nitrogen Species Scavenging}

The production of reactive species provides beneficial health effects in various physiological processes, including host defense against infectious agents and cell signaling $[59,60]$. On the other hand, an imbalance between the pro-oxidant reactive species and the antioxidant defense capacity of cells promotes oxidative stress with harmful effects on cellular components (e.g., lipids, proteins and DNA) [59,61]. The overproduction of reactive oxygen species (ROS) and reactive nitrogen species (RNS) is closely related to pathophysiology of several diseases, such as cancer, diabetes, cardiovascular and neurological disorders as well as skin aging [59-61]. In this sense, plant extracts exert a protective role against oxidative stress-mediated conditions, helping to ensure the equilibrium of antioxidant defenses and to scavenge pro-oxidant species $[60,61]$. The scavenging capacity of olive fruit and leaf extracts enriched with oleuropein against the ROS and RNS studied is summarized in Table 3.

Table 3. ROS/RNS of both olive byproduct extracts $\left(\mathrm{IC}_{50}, \mu \mathrm{g} / \mathrm{mL}\right)$.

\begin{tabular}{cccc}
\hline & HOCl & O2 $^{\bullet-}$ & NO $^{\bullet}$ \\
\hline O.europaea byproduct extracts & \\
\hline O20 & $33 \pm 2^{\mathrm{a}}$ & $29 \pm 2^{\mathrm{a}}$ & $1.7 \pm 0.1^{\mathrm{a}}$ \\
\hline O30 & $34 \pm 3^{\mathrm{a}}$ & $20.0 \pm 0.6^{\mathrm{a}}$ & $1.7 \pm 0.1^{\mathrm{a}}$ \\
\hline Gallic acid & \multicolumn{2}{c}{ Positive controls } \\
\hline Catechin & $4.0 \pm 0.4^{\mathrm{b}}$ & $6.0 \pm 0.5^{\mathrm{b}}$ & $0.20 \pm 0.03^{\mathrm{b}}$ \\
\hline & $0.42 \pm 0.03^{\mathrm{b}}$ & $43 \pm 4^{\mathrm{c}}$ & $0.95 \pm 0.04^{\mathrm{c}}$ \\
\hline
\end{tabular}

$\overline{\mathrm{IC}_{50}}=$ In vitro concentration required to reduce the reactivity of the tested reactive species by $50 \%$ (mean \pm standard error of mean). Different letters $\left({ }^{a}, b, c\right)$ in the same column indicate significant differences between extracts and positive controls $(p<0.05)$.

The O. europaea fruit and leaf extract enriched with $30 \%$ oleuropein (O30) was the most effective scavenger for all ROS and RNS tested. The highest quenching efficiencies were achieved for $\mathrm{NO}^{\bullet}\left(\mathrm{IC}_{50}=1.7 \mu \mathrm{g} / \mathrm{mL}\right)$ and $\mathrm{O}_{2}{ }^{\bullet-}\left(\mathrm{IC}_{50}=20.1-29 \mu \mathrm{g} / \mathrm{mL}\right)$. It is noteworthy that a detailed evaluation of the in vitro radical scavenging activity of industrial olive byproduct-enriched extracts is provided for the first time in this paper, comprising an 
opening field of research. In fact, our values are higher than those reported in commercial micronized powdered olive leaves by Goldschmidt et al. for all ROS/RNS assays [52,62].

$\mathrm{O}_{2}{ }^{\bullet-}$ is the first radical formed during oxidative processes by NADPH oxidase and is quickly transformed into more potent reactive species [59]. The $\mathrm{O}_{2}{ }^{\bullet-}$ scavenging efficiency decreased in the following order: gallic acid $>\mathrm{O} 30$ extract $>\mathrm{O} 20$ extract $>$ catechin. Among samples, the best $\mathrm{O}_{2}{ }^{\bullet-}$ scavenger was the $\mathrm{O} 30$ extract $\left(\mathrm{IC}_{50}=20.1 \mu \mathrm{g} / \mathrm{mL}\right)$, while the O20 extract displayed the lowest quenching capacity based on the highest $\mathrm{IC}_{50}$ value $\left(\mathrm{IC}_{50}=29 \mu \mathrm{g} / \mathrm{mL}\right)$. Gallic acid $\left(\mathrm{IC}_{50}=6.0 \mu \mathrm{g} / \mathrm{mL}\right)$ exhibited the highest $\mathrm{O}_{2}{ }^{\bullet-}$ scavenging ability, while catechin showed the lowest quenching capacity $\left(\mathrm{IC}_{50}=43 \mu \mathrm{g} / \mathrm{mL}\right)$. Significant differences $(p<0.05)$ were observed for gallic acid and catechin, while O20 and O30 extracts were not significantly different $(p>0.05)$. However, both extracts were statistically different $(p<0.05)$ from the positive controls. These results were in line with those documented for Psidium cattleianum pulp extract $\left(\mathrm{IC}_{50}=20.6 \mu \mathrm{g} / \mathrm{mL}\right)$ [61]. Nevertheless, olive leaves, walnut leaves and hardy kiwi leaves revealed a lower capacity to quench $\mathrm{O}_{2}{ }^{\bullet-}$ (with $\mathrm{IC}_{50}$ values of $0.047-0.386 \mathrm{mg} / \mathrm{mL}, 47.6 \mu \mathrm{g} / \mathrm{mL}$ and $53.74 \mu \mathrm{g} / \mathrm{mL}$, respectively) [63-65]. Additionally, Kumar et al. also reported lower $\mathrm{O}_{2}{ }^{\bullet-}$ quenching power for a methanolic extract of Indigofera cassioides leaves $\left(\mathrm{IC}_{50}=232.0 \mu \mathrm{g} / \mathrm{mL}\right)$ [66]. On the other hand, Castanea sativa and Quercus robur leaf extracts exhibited higher $\mathrm{O}_{2}{ }^{\bullet-}$ scavenging ability associated with lower $\mathrm{IC}_{50}$ values (13.6 and $11.0 \mu \mathrm{g} / \mathrm{mL}$, respectively) [67].

$\mathrm{HOCl}$ is a powerful reactive species which results from the reaction between $\mathrm{H}_{2} \mathrm{O}_{2}$ and chloride ions catalyzed by myeloperoxidase enzymes abundantly present in mammalian granulocytic leukocytes [59]. Concerning to the $\mathrm{HOCl}$ scavenging assay, catechin $\left(\mathrm{IC}_{50}=0.42 \mu \mathrm{g} / \mathrm{mL}\right)$ was the best quencher, followed by gallic acid $\left(\mathrm{IC}_{50}=4.0 \mu \mathrm{g} / \mathrm{mL}\right), \mathrm{O} 20$ $\left(\mathrm{IC}_{50}=33 \mu \mathrm{g} / \mathrm{mL}\right)$ and $\mathrm{O} 30$ extracts $\left(\mathrm{IC}_{50}=34 \mu \mathrm{g} / \mathrm{mL}\right)$. The extracts presented similar results evidenced by the absence of statistical differences $(p>0.05)$. No significant differences were observed for catechin and gallic acid. Otherwise, both extracts displayed significant differences $(p<0.05)$ towards positive controls. Similar $\mathrm{HOCl}$ scavenging capacities were reported for Citharexylum solanaceum pulp, skin and seed extracts $\left(\mathrm{IC}_{50}=22.8-64.0 \mu \mathrm{g} / \mathrm{mL}\right)$, as well as Caryocar villosum pulp ( $\left.\mathrm{IC}_{50}=3.6-299.0 \mu \mathrm{g} / \mathrm{mL}\right)$ and $P$. cattleianum skin extracts $\left(\mathrm{IC}_{50}=32.0 \mu \mathrm{g} / \mathrm{mL}\right)[60,61,68]$. Moreover, the present results are substantially higher than those obtained by Reinoso et al. for C. sativa leaves $\left(\mathrm{IC}_{50}=63.8 \mu \mathrm{g} / \mathrm{mL}\right)$ [69].

$\mathrm{NO}^{\bullet}$ is a reactive species generated by the conversion reaction of L-arginine to Lcitrulline catalyzed by nitric oxide synthase. This reactive species is involved in various physiological processes, including inflammation and immune response, and may be used as a precursor of peroxynitrite $\left(\mathrm{ONOO}^{-}\right)$, which is a more damaging reactive species [59]. The $\mathrm{IC}_{50}$ values of extracts and positive controls in this scavenging assay increased in the following order: gallic acid < catechin < O20 extract $<$ O30 extract, with gallic acid $\left(\mathrm{IC}_{50}=0.20 \mu \mathrm{g} / \mathrm{mL}\right)$ and catechin $\left(\mathrm{IC}_{50}=0.95 \mu \mathrm{g} / \mathrm{mL}\right)$ exhibiting the highest $\mathrm{NO}^{\bullet}$ quenching activity. The extracts were significantly different $(p<0.05)$ when compared to gallic acid and catechin. Otherwise, no significant differences $(p>0.05)$ were detected between both extracts that exhibited similar $\mathrm{IC}_{50}$ values $(1.65$ and $1.73 \mu \mathrm{g} / \mathrm{mL}$ for O20 and O30 extracts, respectively). These results were in accordance with those reported for walnut leaves $\left(\mathrm{IC}_{50}=1.95 \mu \mathrm{g} / \mathrm{mL}\right)$ [64]. A lower $\mathrm{NO}^{\bullet}$ quenching potential was observed for leaf extracts from $C$. sativa $\left(\mathrm{IC}_{50}=3.10 \mu \mathrm{g} / \mathrm{mL}\right), Q$. robur $\left(\mathrm{IC}_{50}=3.13 \mu \mathrm{g} / \mathrm{mL}\right)$ and A. arguta $\left(\mathrm{IC}_{50}=3.80 \mu \mathrm{g} / \mathrm{mL}\right)[64,67]$. Likewise, when compared to $P$. cattleianum skin and pulp $\left(\mathrm{IC}_{50}=2.2-6.8 \mu \mathrm{g} / \mathrm{mL}\right)$ and $C$. villosum pulp extracts $\left(\mathrm{IC}_{50}=2.8-142 \mu \mathrm{g} / \mathrm{mL}\right)$, the obtained results were also considerably higher $[60,61]$. In addition, Puerta et al. investigated the scavenging power of the main phenolic compounds identified in olive oil, namely, oleuropein, caffeic acid and hydroxytyrosol. Caffeic acid revealed the highest $\mathrm{NO} \bullet$ quenching power (65\% of inhibition), while the other polyphenols only achieved 50\% of inhibition [70].

The promising outcomes of O. europaea byproduct extracts in the scavenging of ROS and RNS studied may be due to the phenolic composition, especially oleuropein as reported in the previous sections, whose scavenging capacity has already been described in previous studies $[70,71]$. 


\subsubsection{Enzyme Inhibition}

Concerning the cosmetic potential evaluation of olive byproducts, it is noteworthy that studies in the literature are scarce, although surprisingly, the number of olive-based cosmetic products in the market is very high. Several studies demonstrate that olive byproducts possess antipigmentation potential inhibiting tyrosinase and other cosmetic properties. For example, the O. europaea flowers showed interesting elastase and collagenase inhibition potentials [72]. In fact, hyaluronidase and elastase inhibitory activities have been evaluated in other different herbal extracts [73,74]. By catalyzing the hydrolysis of hyaluronic acid, hyaluronidase decreases the viscosity of body fluids and increases the permeability of connective tissues [75]. In the present study, the hyaluronidase inhibition test showed values of $\mathrm{IC}_{50}=55 \pm 1 \mu \mathrm{g} / \mathrm{mL}$ for $\mathrm{O} 20$ and $\mathrm{IC}_{50}=100.1 \pm 0.8 \mu \mathrm{g} / \mathrm{mL}$ for O30, which are higher than those reported previously for other plant extracts [74]. Interestingly, O20 presented a better result than O30, which could be related to the presence of some iridoids that were only detected in O20. Regarding elastase, this enzyme plays an important role in skin aging since the excessive hydrolysis of the dermal elastin fiber network leads to the loss of skin elasticity and consequent skin sagging [76]. In O20 and O30 extracts, the percentage of inhibiting elastase was $19.08 \pm 0.03 \%$ and $20.12 \pm 0.05 \%$ at $250 \mu \mathrm{g} / \mathrm{mL}$, respectively. It is noteworthy that Puerta et al. investigated the inhibitory effects of the major bioactive compounds present in virgin olive oil on elastase activity [70]. Similar elastase inhibition percentages were reported for oleuropein extracted from olive leaves, hydroxytyrosol and caffeic acid at concentrations of 1 and $0.5 \mathrm{mM}(65-75 \%$ and $50-55 \%$ of inhibition, respectively) [70]. The promising potential of these byproducts against skin damages related to aging by elastase and hyaluronidase inhibition was reported for the first time, providing a starting point of cosmetic development.

\subsubsection{Cell Viability}

The effects of $\mathrm{O} 20$ and $\mathrm{O} 30$ extracts on skin cell lines are of utmost importance to evaluate the potentialities of these extracts as active cosmetic ingredients. Keratinocytes are the major cells found in the epidermis, which is the outermost skin layer and where cosmetics are applied [64]. The viability of keratinocytes was investigated as a preliminary study to ascertain the concentrations of extracts that showed absence of toxicity, which is a mandatory requirement for cosmetic ingredients $[33,64]$. In this way, keratinocytes, as the most superficial skin cells, were exposed to different concentrations $(0.1-1000 \mu \mathrm{g} / \mathrm{mL})$ of both extracts, medium (positive control) and triton X-100 (negative control). The results are summarized in Table 4.

Table 4. Effects of exposure to $\mathrm{O} 20$ and $\mathrm{O} 30$ extracts on the viability of keratinocytes at different concentrations, as measured by the MTT assay.

\begin{tabular}{ccccccc}
\hline & \multicolumn{6}{c}{ Concentrations $(\mu \mathrm{g} / \mathbf{m L})$} \\
\hline Medium & $\mathbf{0 . 1}$ & $\mathbf{1}$ & $\mathbf{1 0}$ & $\mathbf{1 0 0}$ & $\mathbf{1 0 0 0}$ \\
\hline Triton X-100 & $0.00 \pm 0.00$ & $0.00 \pm 0.00$ & $0.00 \pm 0.00$ & $0.00 \pm 0.00$ & $0.00 \pm 0.00$ \\
\hline O20 & $100.23 \pm 20.82$ & $100.21 \pm 21.94$ & $113.60 \pm 22.86$ & $106.79 \pm 17.60$ & $61.05 \pm 10.86^{*}$ \\
\hline O30 & $100.63 \pm 7.08$ & $105.65 \pm 14.45$ & $98.92 \pm 14.82$ & $107.31 \pm 8.64$ & $42.06 \pm 5.33 *$ \\
\hline
\end{tabular}

Values are expressed as mean \pm standard deviation $(n=4) .{ }^{*} p<0.05$ vs. control. MTT: 3-(4,5-dimethylthiazol-2-yl)-2,5-diphenyltetrazolium bromide.

The HaCaT cell line viability did not decrease after exposure to different concentrations of $\mathrm{O} 20$ and $\mathrm{O} 30$, showing a viability increase of around $100 \%$ until a concentration of $100 \mu \mathrm{g} / \mathrm{mL}$. Until this concentration, no significant differences $(p>0.05)$ were detected between the extracts and medium exposure. Nevertheless, at the highest concentration tested $(1000 \mu \mathrm{g} / \mathrm{mL})$, the cell viability decreased to 61.05 and $42.06 \%$, respectively, after 
exposure to $\mathrm{O} 20$ and $\mathrm{O} 30$ extracts. The differences observed between O20 and O30 may be due to the different bioactive compounds extracted, as reported in Table 1. To the best of our knowledge, this is the first study that explores the effects of these commercial extracts on skin cell lines by MTT assay. Nevertheless, Schlupp et al. investigated the viability of keratinocytes by WST-1 assay after exposure to an olive mill wastewater extract [77]. The results revealed a considerable decrease in $\mathrm{HaCaT}$ viability for the extract dilution of 1:100 (70.9\%) after $72 \mathrm{~h}$. Otherwise, extract dilutions from 1:200 to 1:1000 showed $\mathrm{HaCaT}$ viabilities above $100 \%$ [77]. The present results are also in line with those obtained by Lameirão et al. for chestnut extracts obtained by ultrasound-assisted extraction [33]. The authors reported viabilities around $65 \%$ for keratinocytes after exposure to a concentration of $1000 \mu \mathrm{g} / \mathrm{mL}$. In another study, Marangi et al. exposed keratinocytes to hardy kiwi leaves extracted by multifrequency multimode modulated technology, reporting a viability of $97 \%$ after exposure to a concentration of $500 \mu \mathrm{g} / \mathrm{mL}$ [64]. It is likely that the different compounds extracted are responsible for these different results. In this sense, MTT assay revealed an optimal range of $\mathrm{O} 20$ and $\mathrm{O} 30$ extract concentrations up to $100 \mu \mathrm{g} / \mathrm{mL}$, suggesting the safety of olive fruit and leaf extracts for skin application and encouraging their use as cosmetic ingredients. However, further studies will be performed to ensure the safety and efficacy of these extracts, particularly concerning ROS effects on skin cell lines (such as $\mathrm{HaCaT}$ cells), skin irritation tests using in vitro validated models (Episkin ${ }^{\circledR}$ ) and ex vivo skin permeation through Franz diffusion cells.

\section{Conclusions}

The phytochemical composition of industrial olive byproducts makes these bioactive extracts attractive ingredients to be incorporated into cosmetic formulations. The extracts screened in the present study were obtained with a feasible and cost-effective scaling-up process using green solvents and inexpensive, renewable and abundant raw material. However, it is necessary to stimulate innovative approaches in cosmetics and to explain their potentialities to olive producers in order to highlight their use as new raw materials.

In the present study, a robust HPLC-QTOF platform was employed to identify a total of 49 compounds; among them, 28 were found in both $\mathrm{O} 20$ and $\mathrm{O} 30$ extracts. A higher abundance of oleuropein and its related compounds was found in O30, whereas O20 was characterized by a major number of iridoids. Moreover, this work reported for the first time in olive leaves the presence of oleuropein-related compound (48), iridoids $(12,15,16$, $17,21,25)$, paniculin (26) and other compounds ( 7 and 24). All detected compounds were demonstrated to possess a strong potential against oxidative stress and aging as reflected in bioactivity performed assays. Specifically, O30 showed higher values in all experiments, except in $\mathrm{HOCl}$ scavenging and hyaluronidase inhibition, where $\mathrm{O} 20$ obtained the best results. Regarding cell viability assays, between 0.1 and $100 \mu \mathrm{g} / \mathrm{mL}, \mathrm{O} 20$ and $\mathrm{O} 30 \mathrm{did}$ not lead to a decrease in viability. However, at the highest concentration tested $(1000 \mu \mathrm{g} / \mathrm{mL})$, both extracts resulted in viabilities of around 42 and $62 \%$, respectively.

The promising potential of industrial olive byproducts as cosmetic ingredients demonstrated in this work is a great starting point for future perspectives that can be concluded with these industrial oleuropein-rich extracts from olive byproducts as bioactive ingredients, allowing the development of new added value products under a biocircular economy model.

Author Contributions: Conceptualization, F.R. and M.d.l.L.C.-G.; methodology, F.R., M.d.l.L.C.-G. and D.P.; validation, F.R. and C.D.-M.; formal analysis, M.d.l.L.C.-G.; investigation, M.d.l.L.C.-G. and D.P.; resources, F.R. and C.D.-M.; data curation, F.R.; writing-original draft preparation, M.d.l.L.C.G.; writing—review and editing, F.R., M.d.l.L.C.-G. and D.P.; visualization, F.R. and M.d.l.L.C.-G.; supervision, F.R. and C.D.-M.; project administration, F.R. All authors have read and agreed to the published version of the manuscript.

Funding: This research received no external funding.

Institutional Review Board Statement: Not applicable. 
Informed Consent Statement: Not applicable.

Data Availability Statement: Not applicable.

Acknowledgments: María de la Luz Cádiz-Gurrea is also grateful to the University of Granada for a "Perfeccionamiento de Doctores" postdoctoral contract. Diana Pinto is thankful for the PhD grant (SFRH/BD/144534/2019) financed by POPH-QREN and subsidized by the European Science Foundation and Ministério da Ciência, Tecnologia e Ensino Superior. Francisca Rodrigues is thankful for her contract (CEECIND/01886/2020) financed by FCT/MCTES-CEEC Individual 2020 Program Contract. The authors are grateful to Sortegel for the samples. This work received financial support from project PTDC/ASP-AGR/29277/2017-Castanea sativa shells as a new source of active ingredients for Functional Food and Cosmetic applications: a sustainable approach, supported by national funds by FCT/MCTES and co-supported by Fundo Europeu de Desenvolvimento Regional (FEDER) throughout COMPETE 2020-Programa Operacional Competitividade e Internacionalização (POCI01-0145-FEDER-029277). This work was also supported by UIDB/50006/2020 and UIDP/50006/2020 by the Fundação para a Ciência e a Tecnologia (FCT)/Ministério da Ciência, Tecnologia e Ensino Superior (MCTES) through national funds.

Conflicts of Interest: The authors declare no conflict of interest.

\section{References}

1. FAOSTAT. Production of Olives. Available online: http://www.fao.org/faostat/en/\#data/QC/visualize (accessed on 13 December 2020).

2. $\quad$ Rodrigues, F.; Pimentel, F.B.; Oliveira, M.B.P.P. Olive by-products: Challenge application in cosmetic industry. Ind. Crops Prod. 2015, 70, 116-124. [CrossRef]

3. Leva, A. Olive Tree in the Mediterranean Area: A Mirror of the Tradition and the Biotechnological Innovation; Leva, A., Ed.; Nova Science Publishers, Inc.: New York, NY, USA, 2018; ISBN 978-1-53614-307-2.

4. Nunes, M.A.; Pimentel, F.B.; Costa, A.S.G.; Alves, R.C.; Oliveira, M.B.P.P. Olive by-products for functional and food applications: Challenging opportunities to face environmental constraints. Innov. Food Sci. Emerg. Technol. 2016, 35, 139-148. [CrossRef]

5. Guermazi, Z.; Gharsallaoui, M.; Perri, E.; Gabsi, S.; Benincasa, C. Integrated approach for the eco design of a new process through the life cycle analysis of olive oil: Total use of olive by-products. Eur. J. Lipid Sci. Technol. 2017, 119, 1700009. [CrossRef]

6. Arvanitoyannis, I.S.; Kassaveti, A. Current and potential uses of composted olive oil waste. Int. J. Food Sci. Technol. 2007, 42, 281-295. [CrossRef]

7. Gullón, B.; Gullón, P.; Eibes, G.; Cara, C.; De Torres, A.; López-Linares, J.C.; Ruiz, E.; Castro, E. Valorisation of olive agro-industrial by-products as a source of bioactive compounds. Sci. Total Environ. 2018, 645, 533-542. [CrossRef] [PubMed]

8. Caleja, C.; Finimundy, T.C.; Pereira, C.; Barros, L.; Calhelha, R.C.; Sokovic, M.; Ivanov, M.; Carvalho, A.M.; Rosa, E.; Ferreira, I.C. Challenges of traditional herbal teas: Plant infusions and their mixtures with bioactive properties. Food Funct. 2019, 10, 5939-5951. [CrossRef] [PubMed]

9. Gorini, I.; Iorio, S.; Ciliberti, R.; Licata, M.; Armocida, G. Olive oil in pharmacological and cosmetic traditions. J. Cosmet. Dermatol. 2019, 18, 1575-1579. [CrossRef] [PubMed]

10. Şahin, S.; Bilgin, M. Olive tree (Olea europaea L.) leaf as a waste by-product of table olive and olive oil industry: A review. J. Sci. Food Agric. 2018, 98, 1271-1279. [CrossRef] [PubMed]

11. Vogel, P.; Machado, I.K.; Garavaglia, J.; Zani, V.T.; de Souza, D.; Dal Bosco, S.M. Beneficios polifenoles hoja de olivo (Olea europaea L.) para la salud humana. Nutr. Hosp. 2015, 31, 1427-1433. [CrossRef]

12. Araki, R.; Fujie, K.; Yuine, N.; Watabe, Y.; Nakata, Y.; Suzuki, H.; Isoda, H.; Hashimoto, K. Olive leaf tea is beneficial for lipid metabolism in adults with prediabetes: An exploratory randomized controlled trial. Nutr. Res. 2019, 67, 60-66. [CrossRef]

13. Yancheva, S.; Mavromatis, P.; Georgieva, L. Polyphenol profile and antioxidant activity of extracts from olive leaves. J. Cent. Eur. Agric. 2016, 17, 154-163. [CrossRef]

14. Rekik, O.; Ben Mansour, A.; Bouaziz, M. Evaluation of phenolic composition and antioxidant activity changes in olive flowers during development using HPLC/DAD and LC-MS/MS. Electrophoresis 2018, 39, 1663-1672. [CrossRef]

15. Taamalli, A.; Arráez-Román, D.; Barrajón-Catalán, E.; Ruiz-Torres, V.; Pérez-Sánchez, A.; Herrero, M.; Ibañez, E.; Micol, V.; Zarrouk, M.; Segura-Carretero, A.; et al. Use of advanced techniques for the extraction of phenolic compounds from Tunisian olive leaves: Phenolic composition and cytotoxicity against human breast cancer cells. Food Chem. Toxicol. 2012, 50, 1817-1825. [CrossRef] [PubMed]

16. Moudache, M.; Colon, M.; Nerín, C.; Zaidi, F. Phenolic content and antioxidant activity of olive by-products and antioxidant film containing olive leaf extract. Food Chem. 2016, 212, 521-527. [CrossRef] [PubMed]

17. Talhaoui, N.; Gómez-Caravaca, A.M.; León, L.; De la Rosa, R.; Segura-Carretero, A.; Fernández-Gutiérrez, A. Determination of phenolic compounds of "Sikitita" olive leaves by HPLC-DAD-TOF-MS. Comparison with its parents "Arbequina" and "Picual" olive leaves. LWT Food Sci. Technol. 2014, 58, 28-34. [CrossRef] 
18. Kashaninejad, M.; Sanz, M.T.; Blanco, B.; Beltrán, S.; Niknam, S.M. Freeze dried extract from olive leaves: Valorisation, extraction kinetics and extract characterization. Food Bioprod. Process. 2020, 124, 196-207. [CrossRef]

19. Žugčić, T.; Abdelkebir, R.; Alcantara, C.; Collado, M.C.; García-Pérez, J.V.; Meléndez-Martínez, A.J.; Režek Jambrak, A.; Lorenzo, J.M.; Barba, F.J. From extraction of valuable compounds to health promoting benefits of olive leaves through bioaccessibility, bioavailability and impact on gut microbiota. Trends Food Sci. Technol. 2019, 83, 63-77. [CrossRef]

20. Barrajón-Catalán, E.; Taamalli, A.; Quirantes-Piné, R.; Roldan-Segura, C.; Arráez-Román, D.; Segura-Carretero, A.; Micol, V.; Zarrouk, M. Differential metabolomic analysis of the potential antiproliferative mechanism of olive leaf extract on the JIMT-1 breast cancer cell line. J. Pharm. Biomed. Anal. 2015, 105, 156-162. [CrossRef]

21. Wang, B.; Qu, J.; Luo, S.; Feng, S.; Li, T.; Yuan, M.; Huang, Y.; Liao, J.; Yang, R.; Ding, C. Optimization of ultrasound-assisted extraction of flavonoids from olive (Olea europaea) leaves, and evaluation of their antioxidant and anticancer activities. Molecules 2018, 23, 2513. [CrossRef]

22. Taamalli, A.; Feriani, A.; Lozano-Sanchez, J.; Ghazouani, L.; El Mufti, A.; Allagui, M.S.; Segura-Carretero, A.; Mhamdi, R.; Arráez-Roman, D. Potential hepatoprotective activity of supercritical carbon dioxide olive leaf extracts against $\mathrm{CCl}_{4}$-induced liver damage. Foods 2020, 9, 804. [CrossRef]

23. Jiménez-Sánchez, C.; Olivares-Vicente, M.; Rodríguez-Pérez, C.; Herranz-López, M.; Lozano-Sánchez, J.; Segura-Carretero, A.; Fernández-Gutiérrez, A.; Encinar, J.A.; Micol, V. AMPK modulatory activity of olive-tree leaves phenolic compounds: Bioassay-guided isolation on adipocyte model and in silico approach. PLoS ONE 2017, 12, e0173074. [CrossRef]

24. Navarro, M.; Morales, F.J.; Ramos, S. Olive leaf extract concentrated in hydroxytyrosol attenuates protein carbonylation and the formation of advanced glycation end products in a hepatic cell line (HepG2). Food Funct. 2017, 8, 944-953. [CrossRef] [PubMed]

25. Singleton, V.L.; Rossi, J.A.J. Colorimetry of total phenolics with phosphomolybdic-phosphotungstic acid reagents. Am. J. Enol. Vit. 1965, 16, 144-158.

26. Benzie, I.F.; Strain, J.J. Ferric reducing/antioxidant power assay: Direct measure of total antioxidant activity of biological fluids and modified version for simultaneous measurement of total antioxidant power and ascorbic acid concentration. Methods Enzymol. 1999, 299, 15-27. [CrossRef] [PubMed]

27. Miller, N.J.; Rice-Evans, C.; Davies, M.J.; Gopinathan, V.; Milner, A. A novel method for measuring antioxidant capacity and its application to monitoring the antioxidant status in premature neonates. Clin. Sci. 1993, 84, 407-412. [CrossRef]

28. Ou, B.; Hampsch-Woodill, M.; Prior, R.L. Development and validation of an improved oxygen radical absorbance capacity assay using fluorescein as the fluorescent probe. J. Agric. Food Chem. 2001, 49, 4619-4626. [CrossRef]

29. Laporta, O.; Pérez-Fons, L.; Mallavia, R.; Caturla, N.; Micolet, V. Isolation, characterization and antioxidant capacity assessment of the bioactive compounds derived from Hypoxis rooperi corm extract (African potato). Food Chem. 2007, 101, 1425-1437. [CrossRef]

30. Pinto, D.; de la Cádiz-Gurrea, M.L.; Sut, S.; Ferreira, A.S.; Leyva-Jimenez, F.J.; Dall'Acqua, S.; Segura-Carretero, A.; Delerue-Matos, C.; Rodrigues, F. Valorisation of underexploited Castanea sativa shells bioactive compounds recovered by Supercritical Fluid Extraction with $\mathrm{CO}_{2}$ : A Response Surface Methodology approach. J. $\mathrm{CO}_{2}$ Util. 2020, 40, 101194. [CrossRef]

31. Nema, N.K.; Maity, N.; Sarkar, B.; Mukherjee, P.K. Cucumis sativus fruit-potential antioxidant, anti-hyaluronidase, and anti-elastase agent. Arch. Dermatol. Res. 2011, 303, 247-252. [CrossRef]

32. Nema, N.K.; Maity, N.; Sarkar, B.K.; Mukherjee, P.K. Matrix metalloproteinase, hyaluronidase and elastase inhibitory potential of standardized extract of Centella asiatica. Pharm. Biol. 2013, 51, 1182-1187. [CrossRef]

33. Lameirão, F.; Pinto, D.; Vieira, E.F.; Peixoto, A.F.; Freire, C.; Sut, S.; Dall'acqua, S.; Costa, P.; Delerue-Matos, C.; Rodrigues, F. Green-sustainable recovery of phenolic and antioxidant compounds from industrial chestnut shells using ultrasound-assisted extraction: Optimization and evaluation of biological activities in vitro. Antioxidants 2020, 9, 267. [CrossRef]

34. Özcan, M.M.; Matthäus, B. A review: Benefit and bioactive properties of olive (Olea europaea L.) leaves. Eur. Food Res. Technol. 2017, 243, 89-99. [CrossRef]

35. Khemakhem, I.; Gargouri, O.D.; Dhouib, A.; Ayadi, M.A.; Bouaziz, M. Oleuropein rich extract from olive leaves by combining microfiltration, ultrafiltration and nanofiltration. Sep. Purif. Technol. 2017, 172, 310-317. [CrossRef]

36. Cardoso, S.M.; Falcão, S.I.; Peres, A.M.; Domingues, M.R.M. Oleuropein/ligstroside isomers and their derivatives in Portuguese olive mill wastewaters. Food Chem. 2011, 129, 291-296. [CrossRef] [PubMed]

37. Rodrigues, F.; Nunes, M.A.; Oliveria, M.B.P.P. Chapter 12-Applications of recovered bioactive compounds in cosmetics and health care products. In Olive Mill Waste; Galanakis, C.M., Ed.; Academic Press: New York, NY, USA, 2017 ; pp. 255-274.

38. Peralbo-Molina, Á.; Priego-Capote, F.; Luque De Castro, M.D. Tentative identification of phenolic compounds in olive pomace extracts using liquid chromatography-tandem mass spectrometry with a quadrupole- quadrupole-time-of-flight mass detector. $J$. Agric. Food Chem. 2012, 60, 11542-11550. [CrossRef]

39. Cardioactive Compounds Isolated from Woody Perennials. Patent No. WO1996010408A1, 11 April 1995.

40. Yuan, H.Y.; Kwaku, O.R.; Pan, H.; Han, J.X.; Yang, C.R.; Xu, M. Iridoid glycosides from the Genus Gentiana (Gentianaceae) and their Chemotaxonomic Sense. Nat. Prod. Commun. 2017, 12, 1663-1670. [CrossRef]

41. Wang, C.; Gong, X.; Bo, A.; Zhang, L.; Zhang, M.; Zang, E.; Zhang, C.; Li, M. Iridoids: Research advances in their phytochemistry, biological activities, and pharmacokinetics. Molecules 2020, 25, 287. [CrossRef] [PubMed]

42. Müller, L.G.; Salles, L.A.; Sakamoto, S.; Stein, A.C.; Cargnin, S.T.; Cassel, E.; Vargas, R.F.; Rates, S.M.K.; Poser, G.L. Effect of storage time and conditions on the diene valepotriates content of the extract of Valeriana glechomifolia obtained by supercritical carbon dioxide. Phytochem. Anal. 2012, 23, 222-227. [CrossRef] 
43. Dührkop, K.; Fleischauer, M.; Ludwig, M.; Aksenov, A.A.; Melnik, A.V.; Meusel, M.; Dorrestein, P.C.; Rousu, J.; Böcker, S. SIRIUS 4: A rapid tool for turning tandem mass spectra into metabolite structure information. Nat. Methods 2019, 16, 299-302. [CrossRef]

44. Christophoridou, S.; Dais, P. Detection and quantification of phenolic compounds in olive oil by high resolution ${ }^{1} \mathrm{H}$ nuclear magnetic resonance spectroscopy. Anal. Chim. Acta 2009, 633, 283-292. [CrossRef]

45. Sugaya, K.; Hashimoto, F.; Ono, M.; Ito, Y.; Masuoka, C.; Nohara, T. Anti-Oxidative constituents from Leonurii Herba (Leonurus japonicus). Food Sci. Technol. Int. 1998, 4, 278-281. [CrossRef]

46. Nie, H.; Huang, S.; Li, X.; Gong, J.; Wu, F.; Yin, J.; Liao, Y.; Wu, S.; Luo, Y. Identification of compounds from chufa (Eleocharis dulcis) peels with inhibitory acrylamide formation activity. Rev. Bras. Farmacogn. 2019, 29, 483-487. [CrossRef]

47. Correia, R.M.; Andrade, R.; Tosato, F.; Nascimento, M.T.; Pereira, L.L.; Araújo, J.B.S.; Pinto, F.E.; Endringer, D.C.; Padovan, M.P.; Castro, E.V.R.; et al. Analysis of Robusta coffee cultivated in agroforestry systems (AFS) by ESI-FT-ICR MS and portable NIR associated with sensory analysis. J. Food Compos. Anal. 2020, 94, 103637. [CrossRef]

48. Rodríguez-Pérez, C.; Zengin, G.; Segura-Carretero, A.; Lobine, D.; Mahomoodally, M.F. Chemical fingerprint and bioactivity evaluation of Globularia orientalis L. and Globularia trichosantha Fisch. \& C. A. Mey, using non-targeted HPLC-ESI-QTOF-MS approach. Phytochem. Anal. 2019, 30, 237-252. [CrossRef]

49. Takac, S.; Karakaya, A. Recovery of phenolic antioxidants from olive mill wastewater. Recent Pat. Biomed. Eng. 2009, 2, $230-237$. [CrossRef]

50. Zhang, H.; Tsao, R. Dietary polyphenols, oxidative stress and antioxidant and anti-inflammatory effects. Curr. Opin. Food Sci. 2016, 8, 33-42. [CrossRef]

51. Irakli, M.; Chatzopoulou, P.; Ekateriniadou, L. Optimization of ultrasound-assisted extraction of phenolic compounds: Oleuropein, phenolic acids, phenolic alcohols and flavonoids from olive leaves and evaluation of its antioxidant activities. Ind. Crops Prod. 2018, 124, 382-388. [CrossRef]

52. Goldschmidt Lins, P.; Marina Piccoli Pugine, S.; Márcio Scatolini, A.; Pires de Melo, M. Antioxidant actions of olive leaf extract (Olea europaea L.) on reactive species scavengers. J. Anal. Pharm. Res. 2020, 9, 68-71. [CrossRef]

53. Orak, H.H.; Karamać, M.; Amarowicz, R.; Orak, A.; Penkacik, K. Genotype-related differences in the phenolic compound profile and antioxidant activity of extracts from olive (Olea europaea L.) leaves. Molecules 2019, 24, 1130. [CrossRef]

54. Kiritsakis, K.; Kontominas, M.G.; Kontogiorgis, C.; Hadjipavlou-Litina, D.; Moustakas, A.; Kiritsakis, A. Composition and antioxidant activity of olive leaf extracts from Greek olive cultivars. J. Am. Oil Chem. Soc. 2010, 87, 369-376. [CrossRef]

55. Khounani, Z.; Hosseinzadeh-Bandbafha, H.; Moustakas, K.; Talebi, A.F.; Goli, S.A.H.; Rajaeifar, M.A.; Khoshnevisan, B.; Jouzani, G.S.; Peng, W.; Kim, K.-H.; et al. Environmental life cycle assessment of different biorefinery platforms valorizing olive wastes to biofuel, phosphate salts, natural antioxidant, and an oxygenated fuel additive (triacetin). J. Clean. Prod. 2021, $278,123916$. [CrossRef]

56. Nunes, M.A.; Páscoa, R.N.M.J.; Alves, R.C.; Costa, A.S.G.; Bessada, S.; Oliveira, M.B.P.P. Fourier transform near infrared spectroscopy as a tool to discriminate olive wastes: The case of monocultivar pomaces. Waste Manag. 2020, 103, 378-387. [CrossRef]

57. Abaza, L.; Youssef, N.B.; Djebali, H.M.; Faouzia, H.; Methenni, K.; Zarrouk, M. Chétoui olive leaf extracts: Influence of the solvent type on phenolics and antioxidant activities. Grasas Aceites 2011, 62, 96-104. [CrossRef]

58. Bermúdez-Oria, A.; Rodríguez-Gutiérrez, G.; Alaiz, M.; Vioque, J.; Girón-Calle, J.; Fernández-Bolaños, J. Polyphenols associated to pectic polysaccharides account for most of the antiproliferative and antioxidant activities in olive extracts. J. Funct. Foods 2019, 62, 103530. [CrossRef]

59. Gomes, A.; Fernandes, E.; Silva, A.M.S.; Santos, C.M.M.; Pinto, D.C.G.A.; Cavaleiro, J.A.S.; Lima, J.L.F.C. 2-Styrylchromones: Novel strong scavengers of reactive oxygen and nitrogen species. Bioorganic Med. Chem. 2007, 15, 6027-6036. [CrossRef]

60. Chisté, R.C.; Freitas, M.; Mercadante, A.Z.; Fernandes, E. The potential of extracts of Caryocar villosum pulp to scavenge reactive oxygen and nitrogen species. Food Chem. 2012, 135, 1740-1749. [CrossRef]

61. Ribeiro, A.B.; Chisté, R.C.; Freitas, M.; Da Silva, A.F.; Visentainer, J.V.; Fernandes, E. Psidium cattleianum fruit extracts are efficient in vitro scavengers of physiologically relevant reactive oxygen and nitrogen species. Food Chem. 2014, 165, 140-148. [CrossRef]

62. Goldschmidt Lins, P.; Piccoli Pugine, S.M.; Scatolini, A.M.; Pires de Melo, M. In vitro antioxidant activity of olive leaf extract (Olea europaea L.) and its protective effect on oxidative damage in human erythrocytes. Heliyon 2018, 4, 805. [CrossRef]

63. Orak, H.H.; Isbilir, S.S.; Yagar, H. Determination of antioxidant properties of lyophilized olive leaf water extracts obtained from 21 different cultivars. Food Sci. Biotechnol. 2012, 21, 1065-1074. [CrossRef]

64. Marangi, F.; Pinto, D.; De Francisco, L.; Alves, R.C.; Puga, H.; Sut, S.; Dall, S.; Rodrigues, F.; Oliveira, M.B.P.P. Hardy kiwi leaves extracted by multi-frequency multimode modulated technology: A sustainable and promising by-product for industry. Food Res. Int. 2018, 112, 184-191. [CrossRef]

65. Almeida, I.F.; Fernandes, E.; Lima, J.L.F.C.; Costa, P.C.; Fernanda Bahia, M. Walnut (Juglans regia) leaf extracts are strong scavengers of pro-oxidant reactive species. Food Chem. 2008, 106, 1014-1020. [CrossRef]

66. Kumar, R.S.; Rajkapoor, B.; Perumal, P. Antioxidant activities of Indigofera cassioides Rottl. Ex. DC. using various in vitro assay models. Asian Pac. J. Trop. Biomed. 2012, 2, 256-261. [CrossRef]

67. Almeida, I.F.; Fernandes, E.; Lima, J.L.F.C.; Costa, P.C.; Bahia, M.F. Protective effect of Castanea sativa and Quercus robur leaf extracts against oxygen and nitrogen reactive species. J. Photochem. Photobiol. B Biol. 2008, 91, 87-95. [CrossRef] 
68. Barizão, É.O.; Visentainer, J.V.; de Cinque Almeida, V.; Ribeiro, D.; Chisté, R.C.; Fernandes, E. Citharexylum solanaceum fruit extracts: Profiles of phenolic compounds and carotenoids and their relation with ROS and RNS scavenging capacities. Food Res. Int. 2016, 86, 24-33. [CrossRef]

69. Reinoso, B.D.; Couto, D.; Moure, A.; Fernandes, E.; Domínguez, H.; Parajó, J.C. Optimization of antioxidants—Extraction from Castanea sativa leaves. Chem. Eng. J. 2012, 203, 101-109. [CrossRef]

70. De La Puerta, R.; Domínguez, M.E.M.; Ruíz-Gutíerrez, V.; Flavill, J.A.; Hoult, J.R.S. Effects of virgin olive oil phenolics on scavenging of reactive nitrogen species and upon nitrergic neurotransmission. Life Sci. 2001, 69, 1213-1222. [CrossRef]

71. Huguet-Casquero, A.; Xu, Y.; Gainza, E.; Pedraz, J.L.; Beloqui, A. Oral delivery of oleuropein-loaded lipid nanocarriers alleviates inflammation and oxidative stress in acute colitis. Int. J. Pharm. 2020, 586, 119515. [CrossRef]

72. Angelis, A.; Mavros, P.; Nikolaou, P.E.; Mitakou, S.; Halabalaki, M.; Skaltsounis, L. Phytochemical analysis of olive flowers' hydroalcoholic extract and in vitro evaluation of tyrosinase, elastase and collagenase inhibition activity. Fitoterapia 2020, 143, 104602. [CrossRef]

73. Chiocchio, I.; Mandrone, M.; Sanna, C.; Maxia, A.; Tacchini, M.; Poli, F. Screening of a hundred plant extracts as tyrosinase and elastase inhibitors, two enzymatic targets of cosmetic interest. Ind. Crops Prod. 2018, 122, 498-505. [CrossRef]

74. Liyanaarachchi, G.D.; Samarasekera, J.K.R.R.; Mahanama, K.R.R.; Hemalal, K.D.P. Tyrosinase, elastase, hyaluronidase, inhibitory and antioxidant activity of Sri Lankan medicinal plants for novel cosmeceuticals. Ind. Crops Prod. 2018, 111, 597-605. [CrossRef]

75. Stern, R.; Jedrzejas, M.J. Hyaluronidases: Their Genomics, Structures, and Mechanisms of Action. Chem. Rev. 2006, 106, 818-839. [CrossRef] [PubMed]

76. Thring, T.S.; Hili, P.; Naughton, D.P. Anti-collagenase, anti-elastase and anti-oxidant activities of extracts from 21 plants. BMC Complement. Altern. Med. 2009, 9, 27. [CrossRef] [PubMed]

77. Schlupp, P.; Schmidts, T.M.; Pössl, A.; Wildenhain, S.; Lo Franco, G.; Lo Franco, A.; Lo Franco, B. Effects of a phenol-enriched purified extract from olive mill wastewater on skin cells. Cosmetics 2019, 6, 30. [CrossRef] 